\title{
O DIALOGISMO E OS 'MEMES' DAS ELEICÕES DE 2018 NAS REDES SOCIAIS
}

\author{
Marcelo Simões Damasceno*
}

RESUMO

O presente estudo busca compreender as relações dialógicas existentes na produção de memes publicados nas redes sociais durante as eleições gerais de 2018. Para tanto, o trabalho foi estruturado da seguinte forma: referência ao conceito de meme baseado na obra de Richard Dawkins; abordagem do dialogismo nas redes socais e os gêneros segundo Mikhail Bakhtin; e análise de memes divulgados durante a campanha eleitoral, mostrando a existência dialógica em sua construção. Concluímos que o meme possui uma produção dialógica, o que possibilita a criação de diferentes réplicas a partir do original. Palavras-chave: Memes, relações dialógicas, redes sociais, discurso.

\section{ABSTRACT}

The present study seeks to understand the dialogical relationships that exist in the production of memes published on social networks during the 2018 general elections. Therefore, the work was structured as follows: a reference to the concept of meme based on the work of Richard Dawkins; then we approach dialogism in social networks and genres according to Bakhtin; finally, using the qualitative method, we carried out the analysis of memes disseminated during the electoral campaign, showing the dialogical existence in its construction. We conclude that the meme has a logic of dialogical production, which allows the creation of different replicas from the original. Keywords: Memes, dialogical relations, social networks, genres of discourse.

\section{INTRODUCÃO}

Há alguns anos, charges, tirinhas e caricaturas, elementos comunicacionais utilizados por empresas jornalísticas, eram aguardadas com ansiedade por leitores de jornais, revistas e sites, pois carregavam uma dose de humor sobre acontecimentos políticos e outros temas do cotidiano. Porém, com

* mdamasceno82@hotmail.com . 
as redes sociais disseminadas na internet, a espera de 24 horas ou de uma semana - no caso das revistas semanais -, pelas peças de humor nos periódicos deixou de ser necessária para os leitores, uma vez que elas ganharam uma divulgação quase que instantânea, e um compartilhamento em massa, principalmente no caso dos memes.

O humor por meio de charges, tirinhas e caricaturas continua existindo na atualidade, porém os memes deram outra dinâmica, ao serem produzidos de forma muito mais rápida para atender à curiosidade do internauta nas redes sociais. Muitos memes são produzidos sem levar em consideração uma excelência técnica ou estética, mas alguns são elaborados seguindo técnicas comunicacionais que podem cumprir a missão de construir ou desconstruir a imagem de uma pessoa. Contudo, este aspecto analítico não será abordado neste estudo.

Este trabalho busca compreender as relações dialógicas presentes na produção de memes que circularam nas redes sociais durante as eleições presidenciais de 2018, tendo como base o pensamento bakhtiniano. Para tanto, apresentamos a origem do termo meme, uma discussão sobre a existência do dialogismo nas interações realizadas nas redes socais, os gêneros do discurso e, após isso, uma análise de quatro memes compartilhados em 2018.

Aqui, o meme foi pensando como um enunciado concreto, como está na teoria de Bakhtin, que o identifica como um gênero típico da comunicação no ambiente digital, e que tem em sua concepção bases dialógicas: sempre que um meme ganha notoriedade e começa a ser compartilhado nas redes socais, surgem diferentes réplicas do enunciado original. Essas são as relações que buscamos investigar neste estudo.

O meme segundo Richard Dawkins

Mesmo sendo um objeto popular das redes sociais, ainda se faz necessário apresentar o significado do termo 'meme', segundo o dicionário digital Priberam": "Meme, substantivo masculino que transmite, por meio de uma imagem: 1, informação ou ideia que se espalha rapidamente através da Internet, correspondendo geralmente à reutilização ou alteração humorística ou satírica de uma imagem; 2, Ideia ou comportamento que passa de uma geração para outra, geralmente por imitação".

\footnotetext{
"Meme", in Dicionário Priberam da Língua Portuguesa [em linha]. Disponível em: https://dicionario.
} priberam.org/meme. Consultado em 13 de jul. de 2020. 
Mas a simplificação do termo não contribui para a sustentação semiótica do fenômeno digital que o objeto se tornou. Para complementar o significado de 'meme', recorremos ao cunhador do termo, o zoólogo Richard Dawkins, autor do livro O gene egoísta, escrito em 1976. Nele o autor demonstra que a seleção natural ${ }^{2}$, princípio básico do darwinismo, não pode ficar restrita aos genes, pois deve abarcar outras unidades que disputam entre si para existir em gerações futuras.

Sendo o gene uma unidade de informação biológica, Dawkins (2007) acredita que é preciso haver uma unidade equivalente no ambiente cultural. $\mathrm{O}$ que mais tarde o fez facultar o conceito de meme para nomear essa nova entidade.

Precisamos de um nome para o novo replicador, um nome que transmita a ideia de uma unidade de transmissão cultural, ou uma unidade de imitação. "Mimeme" provém de uma raiz grega adequada, mas eu procuro uma palavra mais curta que soe mais ou menos como "gene". Espero que meus amigos classicistas me perdoem se abreviar mimeme para meme. Se isso servir de consolo, podemos pensar, alternativamente, que a palavra "meme" guarda relação com "memória", ou com a palavra francesa même. Devemos pronunciá-la de forma a rimar com "creme" (DAWKINS, 2007, p. 330).

Dawkins cita como modelos de memes, que podem ser repassados na mesma linha da teoria da seleção natural de Darwin, "ideias, slogans, modas no vestuário, maneiras de construir arcos", deixando mais claro que os produtos e hábitos do cotidiano seriam as unidades replicadoras apresentadas por ele. "Toda a cultura, todos os comportamentos sociais, todas as ideias e teorias, todo comportamento não geneticamente determinado, tudo que uma pessoa é capaz de imitar ou aprender com uma outra pessoa, é um meme" (TOLEDO, 2009, p. 151).

Neste sentido, da mesma forma que o gene, o meme é uma unidade replicadora que busca a sua perpetuação ao longo do tempo. E para isso, são atribuídas qualidades e estratégias que podem colocá-lo em certa vantagem quando comparado com outros memes. Algo identificável quando pensamos nos memes da internet publicados nas eleições de 2018, e que ainda podem ser vistos nas redes sociais.

\footnotetext{
2 A teoria da seleção natural foi proposta por Charles Darwin, um importante naturalista que mudou o entendimento de como as espécies modificam-se ao longo do tempo. Segundo o autor, há uma luta constante pela sobrevivência, e a seleção natural atua nesse processo. Disponível em: https:// mundoeducacao.uol.com.br/biologia/selecao-natural.htm. Acessado em 13 de jul. de 2020.
} 


\section{O DIALOGISMO NAS REDES SOCIAIS}

As redes sociais, por meio da internet, representam no cotidiano das pessoas uma significativa forma de interação, pela qual é possível emitir opinião e transmitir e receber conteúdo de qualquer parte do mundo. Este é um fator que torna as redes sociais um meio de comunicação vivo, plural e dialógico, possibilitando aos interlocutores em poucos cliques acesso direto a diferentes significações para o mesmo tema ou objeto. Como afirma Leite (2014, p. 216), "é possível consultar informações (outros discursos) a qualquer momento."

A dinâmica que o diálogo tem nas redes se reflete no dialogismo, que por sua vez norteia o pensamento de Mikhail Bakhtin e seu Círculo, que parte do princípio de que a língua é viva e tem como qualidade ser dialógica, e não um conjunto de signos.

A verdadeira substância da língua não é constituída por um sistema abstrato de formas linguísticas nem pela enunciação monológica isolada, nem pelo ato psicofisiológico de sua produção, mas pelo fenômeno social da interação verbal, realizada através da enunciação ou das enunciações (BAKHTIN, 1981, p. 123).

Neste sentido, a relação dialógica não ocorre apenas na interação face a face, mas sim em toda a forma comunicacional, na qual o enunciado de um indivíduo move-se ao encontro de outro, independentemente do espaço físico e da temporalidade, e sempre sendo repassados. Segundo Bakhtin (1981), todo enunciado tem um fato de origem que é transmitido para outro, mas mantendo a origem do tema ou objeto.

Todo discurso concreto (enunciação) encontra aquele objeto para o qual está voltado sempre, por assim dizer, já desacreditado, contestado, avaliado, envolvido por sua névoa escura ou, pelo contrário, iluminado pelos discursos de outrem que já falaram sobre ele. O objeto está amarrado e penetrado por ideias gerais, por pontos de vista, por apreciações de outros e por entonações (BAKHTIN, 2002, p. 86).

A linguagem é utilizada para descrever os objetos existentes, os quais são constantemente descritos nas falas de indivíduos que dialogam. O que para Sousa (2015, p. 3), "vai estabelecer diálogos com o nosso discurso, ao mesmo tempo em que será um prolongamento seu, e abrirá possibilidades para novos discursos." 
[...] o enunciado existente, surgido de maneira significativa num determinado momento social e histórico, não pode deixar de tocar os milhares de fios dialógicos existentes, tecidos pela consciência ideológica em torno de um dado objeto de enunciação, não pode deixar de ser participante ativo do diálogo social (BAKHTIN, 2002, p. 86).

Ainda segundo Bakhtin, o discurso é o prolongamento de um diálogo com réplica, algo que ocorre com frequência nas redes sociais, onde novos valores e significados somam-se ao objeto cada vez que o enunciado amplia a interação entre diferentes indivíduos. O que leva Bakhtin (1981, p. 88) a destacar que "a orientação dialógica é naturalmente um fenômeno próprio a todo o discurso. (...) o discurso se encontra com o discurso de outrem e não pode deixar de participar, com ele, de uma interação viva e tensa."

Diferentes discursos se encontram diariamente nas redes sociais, sejam eles de pessoas que possuem algum vínculo ou que foram aproximadas pelos algoritmos. Isto pode ocasionar uma resposta inesperada pelo receptor desconhecido. De acordo com Bakhtin (1981, p. 89, apud SOUSA, 2015, p. 4), "todo discurso é orientado para a reposta e ele não pode esquivar-se à influência profunda do discurso."

Entende-se que o discurso tem a sua natureza dialógica atestada, uma vez que se orienta para possíveis repostas. Esta é uma ação que pode manter um discurso nas redes vivo por mais tempo, pois algo publicado não está preso ao dia da sua publicação, tornando-se atemporal, e uma interação pode provocar uma reposta que mantém o diálogo ativo.

Segundo o professor José Luiz Fiorin (2006, p.30 - 31), o dialogismo na obra de Bakhtin é composto por três conceitos: "o primeiro conceito de dialogismo diz respeito (...) ao modo de funcionamento real da linguagem: todos os enunciados constituem-se a partir de outros". Já "o segundo pode ser exemplificado pela paródia, pela estilização, pela polêmica clara ou velada, pelo discurso indireto livre". Por fim, no terceiro "o indivíduo constitui-se em relação ao outro. Isso significa que o dialogismo é o princípio de constituição do indivíduo e o seu princípio de ação.”

São as relações das quais os indivíduos participam diariamente nas redes, onde o seu agir é originado em relação aos outros, que tornam cada pessoa um ser não autônomo. Os dois primeiros conceitos são facilmente identificados nas redes sociais, sendo que o segundo constitui uma relação 
dialógica dos memes analisados nas redes sociais, por configurarem por meio da sátira os princípios apontados por Bakhtin.

Sendo assim, no caso dos memes postados nas redes sociais, não se pode negar o dialogismo presente da criação à publicação. Sem um enunciado anterior, a sua compreensão seria inexistente, eliminando assim o seu efeito viral.

\section{A SÁTIRA, A PARÓDIA E A IRONIA EM BAKHTIN}

Como visto, os memes podem ser identificados pelos conceitos do dialogismo de Bakhtin, que ainda podem ser debatidos em outra obra do autor, A cultura popular na Idade Média e no Renascimento: o contexto de François Rebelais (2008). Ela discorre sobre as multiplicidades culturais na Idade Média e no Renascimento, divididas em três categorias.

A primeira diz respeito às obras apresentadas em praças públicas, como festejos carnavalescos, obras cômicas, entre outras. Na sequência estão as obras cômicas orais ou escritas, sejam em latim ou em outro idioma vulgar. Por fim, a terceira aborda as formas do vocábulo tido como grotesco, compostas pelos populares, juramentos, insultos, entre outros (Bakhtin, 2008).

As características dos gêneros do campo sério-cômico possuem uma relação intensa com o folclore carnavalesco. Estes gêneros trazem consigo uma cosmovisão carnavalesca - na qual são determinadas particularidades fundamentais e dadas à imagem e à palavra uma relação com a realidade - específica, sendo que alguns são variantes literárias dos gêneros folclórico-carnavalescos (BAKHTIN, 2005, apud REIS, 2015, p. 26).

Isso mostra o quanto a literatura, indireta ou direta, teve influência nas diferentes formas de manifestações folclóricas, algo que Reis (2015, p. 26) "trata como literatura carnavalizada". O autor cita como exemplo o "sério-cômico", um conjunto de crenças que "são a pluralidade de estilos e variedade de todos esses gêneros. Eles renunciam à unidade estilística [...] da epopeia, caracterizada pela fusão do sublime, do vulgar e da lírica" (BAKHTIN, 2008, p. 108).

Entre os gêneros estão a sátira, um estilo que para o autor é flexível e com capacidade de percorrer outros gêneros (Bakhtin, 2008). Ele ainda reforça a importância dela para o desenvolvimento das literaturas: "a sátira menipeia tornou-se um dos principais veículos e portadores da cosmovisão carnavalesca na literatura até os nossos dias" (BAKHTIN, 2008, p.113). 
Outro gênero é a paródia, definida pelo autor como o estilo responsável pela inversão dos papeis na sociedade, ao presentear indivíduos de classes superiores como inferiores, e vice-versa (Bakhtin, 2008). Este gênero ainda possui três tipos básicos: verbal, com alteração em palavras no texto; formal, a técnica do escriba é usada como forma de zombaria; e temático, faz a caricatura da forma e do espírito do autor ou autores.

Nesta linha, mesmo autores mais contemporâneos definem a paródia também por contiguidade, considerando-a um mero sinônimo de pastiche, ou seja, um trabalho de ajuntar pedaços de diferentes partes de obra de um ou de vários artistas (SANT' ANNA, 2003. P. 13).

Já a ironia é definida por Beth Brait em sua obra Ironia em perspectiva da polifônica (1996) com uma dupla natureza: atitude e procedimento verbal. Brait destaca a ironia como um elemento que pode auxiliar na estrutura textual. "Ela pode auxiliar a compreensão não apenas do discurso literário como a do não literário e de suas especificidades" (BRAIT, 1996, p. 97).

A obra de Bakhtin e seu Círculo oferece os conceitos necessários para a compreensão do objeto deste estudo, uma vez que a produção dos memes utilizados nas eleições de 2018 apresentam indícios dos gêneros discursivos.

\section{OS MEMES E AS RELAÇÕES DIALÓGICAS}

Vale relembrar que a primeira referência sobre meme ocorreu na década de 1970, quando Dawkins (1976) toma por empréstimo os termos gene e memória, para adaptá-los ao processo de perpetuação de ideias como ocorre na genética.

Porém, na atualidade, a origem do termo é desconhecida para muitos dos usuários da internet, onde os memes tornaram-se um fenômeno de compartilhamento por meio de vídeo, gif, imagem, hashtag e website como peças sátiras, cômicas ou irônicas. Esta ação possibilita ao meme atingir um número indefinido de pessoas, o que pode ajudá-lo a permanecer inalterado ou sofrer modificações conforme é repassado.

Algo que contribui na propagação é o uso de hashtag, a palavra-chave, um texto que acompanha a postagem e que pode ajudar o meme a figurar entre os temas mais comentados do dia, além de facilitar a sua busca na internet sempre que pesquisado.

Nos últimos anos, o uso das redes sociais na política, sobretudo nas eleições brasileiras de 2018, foi intensificado. É por elas que as pessoas têm debatido as pautas propostas pelos candidatos, e disseminado ideias, seja 
por meio de perfis pessoais ou por páginas de humor. "Marina ecológica", "Ciro Gomes Zueiro", "Cabo Daciolo Presidente 2018", dentre outras, são exemplos de perfis fakes de candidatos destinados à publicação de conteúdo avesso ao das páginas oficiais, que criam um ambiente pelo qual as interações são construídas entre os integrantes (Recuero, 2012).

É nesta interatividade digital entre os integrantes das redes sociais que apresentamos um recorte do uso de memes na política, tendo como base a obra de Bakhtin. Na sequência, temos uma amostra de memes publicados nas redes, e em seguida uma análise sobre como as relações dialógicas podem ser percebidas na produção dos memes dos candidatos à Presidência da República.

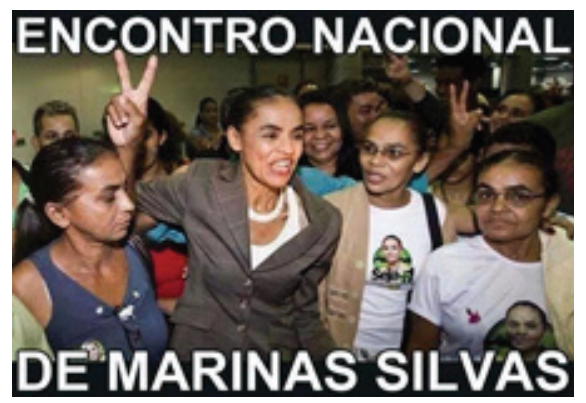

Figura 1: "Meme exército de Marinas Silvas"

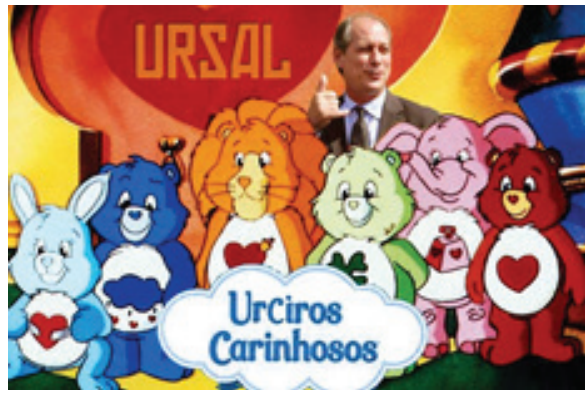

Figura 2: "Cabo Daciolo questiona Ciro Gomes sobre a Ursal (União das Repúblicas Socialistas da América Latina) ${ }^{7 ”}$

Página Marina Ecológica na rede social Facebook. Disponível em: https://www.facebook.com/MarinaEcol\%C3\%B3gica-2206973192892090. Acessado em 13 de jul. de 2020.

4 Página Ciro Gomes Zueiro na rede social Facebook. Disponível em: https://www.facebook.com/ cirogomeszueiro. Acessado em 13 de jul. de 2020.

5 Cabo Daciolo Profetiza na rede social Facebook. Disponível em: https://www.facebook.com/Cabo-Daciolo-Presidente-2018-199522290868453. Acessado em 13 de jul. de 2020.

6 Disponível em: < https://twitter.com/marinasilva/status/1043268596019933185> . Acessado em 13 de Jul. de 2020.

7 Disponível em: < https://www1.folha.uol.com.br/tec/2018/09/cabo-daciolo-vira-game-para-celular. shtml?origin $=$ folha $>$. Acessado em 13 de jul. de 2020 . 


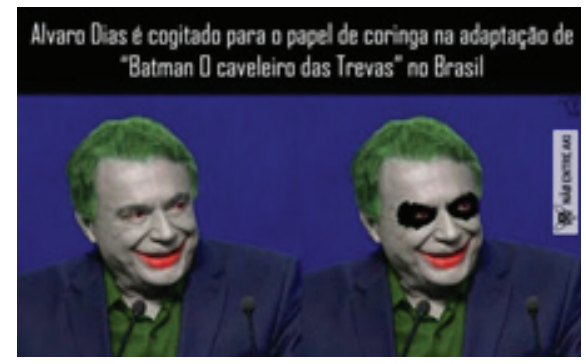

Figura 3: "Álvaro Dias é comparado o personagem Coringa"

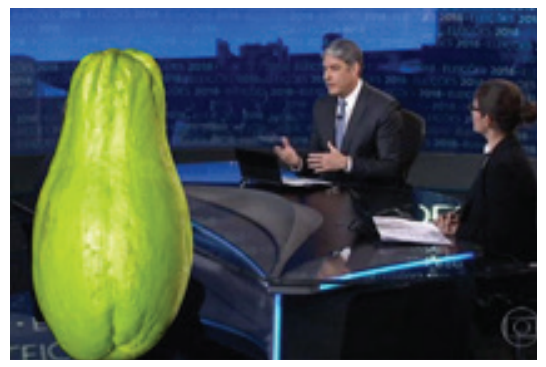

Figuras 4: "Geraldo Alckmin em sabatina do Jornal Nacional"”

As quatro figuras foram escolhidas de forma aleatória. Um recorte simplificado dos memes postados nas redes sociais durante momentos da campanha eleitoral de 2018, pelo qual buscamos a compreensão dos enunciados que mostram não depender apenas de elementos verbais para o seu entendimento.

Nossa avaliação leva em consideração mais que elementos verbais, uma vez que os não verbais colaboram para a compreensão dos memes selecionados. Vale ressaltar que Bakhtin (1976), em sua obra, aponta que o extraverbal pode ser considerado um elemento fora do enunciado, essencial para a sua significação.

Na análise da figura 1, "Meme exército de Marinas Silvas", podemos perceber que os enunciados são colocados de maneira bem-humorada sobre uma foto da candidata Marina Silva junto às suas irmãs. A construção desta postagem possui elementos do segundo tipo de relações dialógicas apontadas

\footnotetext{
Disponível em: < http://www.naoentreaki.com.br/6107470-.htm> . Acessado em 13 de jul. de 2020. Disponível em: < https://www.otempo.com.br/hotsites/elei\%C3\%A7\%C3\%B5es-2018/em-sabatina-do-jornal-nacional-geraldo-alckmin-nao-escapa-de-memes-na-internet-1.2024138>. Acessado em 13 de jul. de 2020 .
} 
por Fiorin (2006), ou seja, a paródia, a ironia e a sátira. Como mencionado, a sátira é uma composição irônica aos costumes, ideias e práticas.

Assim, na primeira figura, o encontro de Marina Silva com as suas irmãs, em um determinado momento da campanha, virou objeto de sátira nas redes, ao ser redefinido como um evento destinado ao encontro nacional das Marinas Silvas, uma vez que as irmãs da candidata possuem traços físicos de visível semelhança, o que segundo Fiorin (2006) é uma forma de dialogismo.

Um autor pode usar o discurso de um outro para seus fins pelo mesmo caminho que imprime nova orientação significativa ao discurso que já tem sua própria orientação e a conserva. Neste caso, esse discurso deve ser sentido como o de um outro. Assim, num único discurso podem-se encontrar duas orientações interpretativas, duas vozes. Assim é o discurso parodístico, a estilização, o skaz estilizado’ (BAKHTIN, 1970, p. 147).

Já a figura 2 faz referência ao debate eleitoral transmitido pela Rede Bandeirantes em 9 de agosto de 2018, quando o candidato Cabo Daciolo questionou o candidato Ciro Gomes sobre o Foro de São Paulo: “O senhor é um dos fundadores do Foro de São Paulo. O que o senhor pode falar aqui para a população brasileira sobre o plano Ursal? O que o senhor tem para dizer?"10" Diante da expressão de surpresa de Ciro Gomes, Daciolo acrescentou: "O plano Ursal. União das Repúblicas Socialistas da América Latina. Tem algo a dizer para a Nação brasileira?". Ciro disse desconhecer o plano e, após uma réplica de Daciolo, encerrou o assunto com um tom irônico. "Democracia é uma delícia, é uma beleza, mas ela tem certos custos”, afirmou.

O diálogo entre os presidenciáveis em poucos minutos despertou a euforia nas redes sociais, onde diferentes indivíduos satirizaram ou ironizaram o fato por meio de memes. Neste, o autor da imagem fez alusão ao desenho infantil "Ursinhos Carinhosos"11", à cor vermelha atribuída aos partidos políticos mais alinhados à esquerda, e usou a foto de Ciro Gomes para a construção do enunciado que faz paródia sobre a fala do Daciolo.

O meme traz a foto de Ciro Gomes ao lado dos ursinhos, um suposto logo da Ursal e os dizeres "Urciros Carinhosos", com a intenção de mate-

10 Disponível em: https://www.correiobraziliense.com.br/app/noticia/politica/2018/08/10/interna_politica,699956/o-que-e-ursal-cabo-daciolo-debate.shtml> . Acessado em 13 de jul. de 2020.

11 Site com a identificação dos Ursinhos Carinhos. Disponível em: http://www.portalursinhoscarinhosos. com.br/personagens/. Acessado em 15 de jul. de 2020. 
rializar em imagem a fala do Daciolo. Ativos que devem ser recuperados pelo contexto social para a sua compreensão (Dawkins, 2007), e que podem contribuir para a sua perpetuação nas redes sociais.

Passemos à análise da figura 3, na qual aparece a imagem do candidato Alvaro Dias caracterizado do personagem Coringa, acompanhado da seguinte frase: "Alvaro Dias é cogitado para o papel de coringa na adaptação de Batman, o cavaleiro das trevas, no Brasil". O objeto da imagem teve como foco o sorriso do candidato, que foi comparado nas redes com o do vilão dos quadrinhos da "DC Comics" ".

O meme trata de uma referência irônica ao sorriso do candidato, que chamou a atenção durante o debate, o que contribui para reforçar a velocidade das redes socais em fazer assimilações e reprodução de conteúdo de forma instantânea, como forma de provocar o humor.

Por fim, na figura 4 aparecem os âncoras do Jornal Nacional, da Rede Globo de Televisão, Renata Vasconcellos e William Bonner, entrevistando um "chuchu". O meme faz referência sátira ao candidato Geraldo Alckmin, que há mais de 15 anos foi apelido de "Picolé de Chuchu ${ }^{13 "}$ pelo jornalista e colunista José Simão, durante as eleições de 2002 para o governo de São Paulo. Desde então, foi amplamente usado em diversas oportunidades nas redes socais.

O meme atribuído ao candidato Alckmin reforça a teoria de Dawkins (2007) que, pelo princípio básico do darwinismo, não pode ficar restrito aos genes. Abarca outros elementos que disputam entre si para se perpetuar em gerações futuras, como ocorreu com este meme.

Além da teoria de Dawkins, podemos identificar o "chuchu" no contexto como um signo que está ligado, mesmo que de forma satírica ou irônica, à vida política de Alckmin. Segundo a perspectiva bakhtiniana, o vegetal seria um signo ideológico. "É não apenas um reflexo, uma sombra da realidade, mas também um fragmento material dessa realidade (BAKHTIN, 1999, p. 33). Isto é, as características que o "chuchu” simboliza no meme acima são fragmentos, valores ideológicos que se materializam na figura de Alckmin. Quando o meme é recebido por alguém que conhece a alcunha do candidato, pode gerar o compartilhamento pela sua lembrança, mesmo sem elemento textual.

\footnotetext{
12 Site da DC Comics com quadrinhos do personagem Coringa e outros. Disponivel em: < http://www. comix.com.br/quadrinhos/dc-comics.html> . Acessado em 15 de jul. de 2020.

13 Disponível em: < https://jovempan.com.br/programas/panico/picole-de-chuchu-alckmin-garante-que-apelido-nao-incomoda-nao-fiquei-bravo-1.html >. Acessado em 13 de jul. de 2020.
} 
As relações dialógicas aqui analisadas são constituídas de inúmeros diálogos que têm como base discursos vivos do cotidiano, sem que o autor tenha conhecimento de todas as falas, pois ele não controla o discurso. Com isso, os memes carregam características dos indivíduos ou objetos para que o efeito do humor tenha o seu objetivo atingido, independentemente do tempo.

\section{CONSIDERACÕES FINAIS}

Durante a pesquisa, foram encontradas diferentes referências que auxiliam na compreensão de como os enunciados dos memes publicados nas redes socais possuem elementos amplamente dialógicos. Foram apresentadas constantemente ideias e contraposições que podem promover debate e reflexão, constituindo assim o dialogismo.

Desta forma, quando um indivíduo faz uma postagem, como nos casos analisados, uma resposta é sempre esperada, gerando um efeito sequencial de respostas. Uma das lógicas nas redes socais é que uma publicação tenha cada vez mais comentários, curtidas e compartilhamentos, o que garante uma temporalidade maior ao tema publicado. Uma ação, como mencionado no estudo, que pode contribuir para que o meme tenha uma vida longa na rede.

O que nos leva a concluir que o processo de interação exposto por Bakhtin - a construção de sentido só existe com a interação de interlocutores - ocorre nas redes sociais por meio de uma comunicação dinâmica, viva, interativa e com a possibilidade de diferentes significações.

Em nossas análises, destacamos os memes dos candidatos à Presidência da República Geraldo Alckmin, Ciro Gomes, Alvaro Dias, Cabo Daciolo e Marina Silva, que ganharam notoriedade ao serem propagados nas redes, o que também provocou diferentes réplicas do original.

Por tanto, constatou-se que a estrutura do enunciado dos memes analisados contém relações dialógicas constituídas pela ironia, sátira e paródia, fazendo com que o indivíduo que receba a mensagem recupere o contexto extraverbal para a sua melhor compreensão, pois apenas o verbal seria insuficiente na ação interpretativa. Isso evidencia que o conhecimento do contexto social, "mundo", se faz presente e necessário para a compreensão do meme.

\section{REFERÊNCIAS BIBLIOGRÁFICAS}

BAKHTIN, Mikhail. A Cultura Popular na Idade Média e no Renascimento: o contexto de François Rabelais. Tradução de Yara Frateschi Vieira. São Paulo: Hucitec; Brasília: Editora Universidade de Brasília, 2008. 
BAKHTIN, M. Os gêneros do discurso. In: Estética da Criação Verbal. Tradução de Maria Ermantina Galvão G. Pereira. São Paulo: Martins Fontes, 2000.

BAKHTIN, Mikhail (Volochinov). [1926]. (VOLOSHINOV) Estrutura do enunciado. Tradução de Ana Vaz, para fins didáticos. 1930.

. Discurso na vida e na arte: sobre a poética sociológica. Trad. de Carlos Alberto Faraco e Cristóvão Tezza da edição inglesa de TITUNIK, I. R. "Discourse in life and discourse in art - concerning sociological poetics”. In: VOLOSHINOV, V. N. Freudism. New York: Academic Press, 1976.

- Marxismo e filosofia da linguagem: problemas fundamentais do método sociológico na ciência da linguagem. Tradução de Michel Lahud e Yara Frateschi Vieira; com a colaboração de Lúcia Teixeira Wisnik e Carlos Henrique D. Chagas Cruz. 2a .ed. São Paulo: Hucitec, 1981.

. Questões de literatura e de estética: a teoria do romance. São Paulo: Hucitec/Anablume, 2002.

. Estética da criação verbal. Tradução de Paulo Bezerra. 6a . ed. São Paulo: Martins Fontes, 2011.

BRAIT, B. Ironia em Perspectiva Polifônica. Campinas: Editora da UNICAMP, 1996.

BRAIT, B. Estilo. In: BRAIT, B. (Org.) Bakhtin: conceitos-chave 4. ed. São Paulo: Contexto, 2008c.

FIORIN, José Luiz. Introdução ao pensamento de Bakhtin. São Paulo: Ática, 2006.

DAWKINS, Richard. O gene Egoísta. São Paulo: Companhia das Letras, 2007.

HORTA, B., Natalha. O meme como linguagem da internet: Uma perspectiva semiótica. https://repositorio.unb.br/bitstream/10482/18420/1/2015_NataliaBotelhoHorta.pdf.Acessado em 11 de jul. de 2020.

REIS. Carolina. As postagens no Facebook, uma análise dialógica da página de humor "Dilma Bolada". Disponível em: http://wwws.fclar.unesp.br/agenda-pos/linguistica_lingua_portuguesa/3599.pdf. Acessado em 15 de mai. De 2020.

RECUERO, R. A conversação em rede: comunicação mediada pelo computador e redes sociais na Internet. Porto Alegre: Sulina, 2012.

SANT'ANNA, A. R de. Paródia, paráfrase \& Cia, Ática, 2003.

SOUSA, Claudemir. As relações dialógicas na produção de “memes na internet”. Disponível em: < http:// www.periodicoseletronicos.ufma.br/index.php/littera/article/view/3561>. Acessado em 9 de mai. de 2020.

ZUBLER, E., LEITE, J., MASO. L. O dialogismo na era digital. Disponível em: < file:///C:/Users/ Marcelo/Desktop/TESE\%20MESTRADO\%20METODISTA\%202019/MATEUS/2954-6957-1-SM.pdf >. Acessado em 9 de jul. de 2020 . 